\title{
Gerçeğin Saçmalığı, Saçmanın Sanatı: Gerçek Sanat Birliği
}

\section{Nonsense of Reality, Art of Nonsense: The Association for Real Art}

\author{
Esma Armağan Ertuğrul ${ }^{1}$ (1)
}

'Yüksek Lisans Öğrencisi, İstanbul Üniversitesi, Sosyal Bilimler Enstitüsü, Tiyatro Eleştirmenliği ve Dramaturji Anabilim Dalı, İstanbul, Türkiye

\section{ORCID: E.E. 0000-0001-7260-045X}

Sorumlu yazar/Corresponding author: Esma Armağan Ertuğrul,

İstanbul Üniversitesi, Sosyal Bilimler Enstitüsü, Tiyatro Eleştirmenliği ve Dramaturji Anabilim Dalı, İstanbul, Türkiye

E-posta/E-mail: ertugrulesma@gmail.com

Başvuru/Submitted: 01.11.2019 Revizyon Talebi/Revision Requested: 12.11.2019

Son Revizyon/Last Revision Received:

29.11.2019

Kabul/Accepted: 02.12 .2019

\section{Atıf/Citation:}

Ertugrul, Esma Armagan. "Gerçeğin Saçmalığı, Saçmanın Sanatı: Gerçek Sanat Birliği" Tiyatro Eleştirmenliği ve Dramaturji Bölümü Dergisi 29, (2019): 65-91.

https://doi.org/10.26650/jtcd.641359
ÖZ

Gerçek Sanat Birliği, Sovyetler Birliği'nde 1927 ile 1930 yılları arasında varlık göstermiş bir edebiyat-sanat topluluğudur. Topluluk, gerek üyeler tarafından yayınlanan ortak manifestoyla gerekse üretilen eserlerle, aynı dönem etkinlik gösteren diğer pek çok gruptan ayrılır. Birliğin saçma, gülünç ve beklenmeyen olanla ilişkisi, ilk gösterimleri “Üç Sol Saat"in ardından karalanmalarına ve topluluk üyelerinin Sovyet karşıtı bir topluluğa üye olmaktan tutuklanmalarına kadar giden bir sürece işaret eder. Dolayısıyla manifestolarında sansüre ve sanatçının özgürlüğünün elinden alınmasına karşı çıkan grup üyeleri de dönemin diğer avangard topluluk ve sanatçılarıyla aynı kaderi paylaşırlar.

Bu çalışmanın amacı, sanatı geçmişin çöpünden kurtarmak için ona dişlerini geçiren avangard topluluk Gerçek Sanat Birliği'ni tanıtmaktır. Bu amaçla Gerçek Sanat Birliği'ne kısaca değinildikten sonra birliğin kurucu üyesi olan Daniil Harms'ın 1927 yılında yazdığı Yelizaveta Bam adlı oyun ve grubun diğer üyelerinin şiir ve kısa yazılarından oluşan seçme çeviriler paylaşılacaktır.

Anahtar Kelimeler: Gerçek Sanat Birliği, OBERiU, Yelizaveta Bam, Daniil Harms, avangard

\section{ABSTRACT}

The Association for Real Art was an arts and literature group that used to be active between the years 1927 and 1930 in the Soviet Union. The community, thanks to their manifesto, co-written by their members, and the works they produced, was different from many of the other communities that were active in the same period. The Association's relation to the absurd, comical and the unexpected resulted in their defamation and accusations of membership to anti-Soviet groups after their first production, "Three Left Hours". Therefore, the members faced the same destiny that their contemporaries and other avantgarde groups had gone through, as they were making statements against censorship and the confiscation of the freedom of expression from artists.

The aim of this study is to introduce the avant-garde The Association for Real Art that clenched art and never let it go to save it from the sewer of the past. After a brief introduction to The Association for Real Art, translations of excerpts from the selected poems and other writings by the community members will be shared, along with the founding member Daniil Kharms' play Elizaveta Bam. Keywords: The Association for Real Art, OBERIU, Elizaveta Bam, Daniil Kharms, avant-garde 


\section{EXTENDED ABSTRACT}

The Association for Real Art (Объединение Реального Искусства) or OBERIU is an arts and literature group that used to be active between the years 1927 and 1930 in the Soviet Union. Many artists such as Malevich and Filonov became close to the community that comprised names such as Daniil Kharms, Aleksander Vvedensky, Konstantin Vaginov, Igor Bakhterev and Nikolay Zabolotsky.

Oberiuty deals with their works in four parts in the manifesto they published. These are literature, visual arts, theatre and cinema. Each of the group members was interested in one of these branches at least, and it was reported that the community carried on work to open a music unit.

Another thing mentioned in the manifesto was that community members needed to transcend art by encompassing it from afar, and near, and bring it to life. The community criticized Russian literacy, which was based on Western bourgeois translation literature and expressed that outmoded literature did not satisfy them. Besides this, a mistake was underlined: The avant-garde artists, who were held in high honour during the October Revolution, began to be smeared after the revolution. The mission that was attributed to art for creating the Soviet person played an important role here. Thus, avant-garde artists, who were regarded as the pioneers of the new order before the revolution, were accused for bourgeoisie and anti-Sovietism, to the extent that they did not provide the mission dictated to them after the revolution. What was done to artists whose works were boycotted, exhibitions were cancelled and works were censored does not end there. When socialist realism becomes the official ideology at the Soviet Writers's First Congress, it was forbidden to produce works in different ideologies. In addition to those arrested and deported, some artists fled abroad in this process. Those who could not flee abroad were condemned to starvation, disease and death by being prevented from working. This is also what happened to most of the members of The Association for Real Art in the upcoming periods.

The first and only production of The Association for Real Art, "Three Left Hours", took place on January 24, 1928. In the three-part presentation, the manifesto of the community was read, a poetry recitation consisting of works written by the members of the group was performed, the play Elizaveta Bam by Daniil Kharms was staged and the movie The Meat Grinder was presented.

Elizaveta Bam created shock in the audience; because it was far beyond the usual forms, both structurally and in terms of content. The play begins with the protagonist Elizaveta Bam getting on the stage with fear of being arrested. Someone is after her and Elizaveta Bam looks for a place to hide from those people whom she thinks will scrape her off the face of the earth. 
However, the expected people arrive quickly and say that they will arrest Elizaveta Bam. When Elizaveta Bam asks for the reason, she receives no answer other than that she is found guilty. Fortunately, Elizaveta Bam finds an opportunity to play off the incoming duo against each other, and the tense moments are replaced by an absurd chase.

A lot of absurd things happen during the play. Daniil Kharms' relation to the language particularly gives the play a quite different vitality and rhythm. The inconsistent and even nonsensical speech of the characters in the play causes us to think about the meaninglessness of existence, and the liberating side of this meaninglessness. The author's relation to the game is reflected in the actions of the characters and for the audience or reader, the play within the play becomes a nonsensical but entertaining track.

What makes the play important is not only that it is structurally different from its predecessors. The play says a lot of things politically, too. The protagonist's fear of being arrested reveals the fears of the Stalin-Era Soviet people. Elizaveta Bam is found guilty of an unknown matter and runs away because of fear of being killed. But when she is arrested, it is unknown what will happen to her in the future.

The aim of this study is to introduce The Association for Real Art and present the translation of play Elizaveta Bam by Daniil Harms. After a brief introduction, translations of excerpts from the selected poems and other writings by the community members will be shared. 


\section{GERÇEĞIIN SAÇMALIĞI, SAÇMANIN SANATI: GERÇEK SANAT BİRLİĞİ}

“Beni, hiçbir pratik anlamı olmayan 'saçma'ilgilendiriyor sadece. Hayatın abes tezahürü çekiyor yalnız ilgimi. Kahramanlık, pathos, yiğitlik, ahlak, hijyen, ahlaklılık, duygulanım ve coşku, nefret edilesi duygular ve sözcüklerdir benim için. Fakat tümüyle anllyor ve saygl duyuyorum coşkuya ve hayranliğa, ümitsizliğe ve esine, tutkuya ve dizginlemeye, şehvete ve erdeme, actya ve kedere, kahkahaya ve sevince."

31 Ekim 1937

D. Harms ${ }^{12}$

Gerçek Sanat Birliği (Obyedineniye Realnovo İskusstva/ Объединение Реального Искусства) уа da OBERIU (ОБЭРИУ), Gümüş Çă̆' $1 n^{3}$ son avangard edebiyat-sanat topluluğudur. 1927 yılında faaliyet göstermeye başlayan topluluğun isminin kısaltması olan OBERIU'nun son harfi "U”, alışılageldik sanat-felsefe akımlarındaki “izm”e karşılık gelecek şekilde özgün bir son ek olarak türetilmiş ve grup üyeleri tarafından topluluğun adının kısaltmasına eklenmiştir. ${ }^{4}$ Grubun isminin kısaltmasına anlamdan bağımsız bir şekilde eklenen bu harf, topluluğun geleneği yadsıyan dünya görüşünü ve anlamsızla aralarında kurdukları bağı göstermesi açısından önemlidir.

Topluluk, 1927'den 1930'a kadar varlık gösterse de grup üyelerinin tanışıklıkları, Gerçek Sanat Birliğgi'nin kurucusu Daniil Harms’ın, 1925’te Aleksandr Vvedenskiy’nin başını çektiği

1 Daniil Harms, "Boje, kakaya ujasnaya jizn i kakoye ujasnoye u menya sostoyaniye", Novly Mir 2 (1992), 218.

2 Çalışma boyunca herhangi bir Türkçe esere referans verilmeden çevirisi bulunan bu ve diğer kısımların çevirisi tarafima aittir.

3 Rus edebiyatında 1890'lardan 1930'lara değin süren dönem “Gümüş Çağ” olarak adlandırılır (Bu çalışmada Gümüş Çağ, 1930'lu yıllara kadar süren bir dönem olarak ele alınsa da bu konuda farklı görüşler vardır. Gümüş Çağ'ın bitiş tarihi olarak kimi eleştirmenler, devrimin gerçekleştiği 1917 yılını gösterirlerken kimileri bu tarihi, SSCB’nin “sosyalist realizmi” edebi alanda resmi akım olarak benimsediği 1934 yılına kadar götürür). Gümüş Çağ’ın oluşmasına zemin hazırlayan etmenler, devrim öncesi Rusya'nın içinde bulunduğu kaotik hal ve modernizmdir. Bu döneme "Gümüş Çağ” denmesi, kavramsal olarak kendinden önceki bir “Altın Çă̆"a gönderme yapar. V. V. Rozanov, Rus edebiyatında Karamzin'den (1766-1826) başlayarak Gogol'e (18091852) kadarki süreci Rus edebiyatının “Altın Çă̆”’ olarak nitelendirir (Bkz. Vasiliy Vasilyeviç Rozanov, $O$ Pisatelstve i pisatelyah (Moskva: İzdatelstvo «Respublika», 1995), 145.) Bu kavramsallaştırma, Gümüş Çağ’da verilen eserlerin, Altın Çağ' da verilen eserlerden daha değersiz olduğu yönünde olumsuz bir çağrışım yapsa da edebi açıdan Altın Çağ ile Gümüş Çağ’ 1 kıyaslamak ve bunlar arasından birini değerli, ötekini değersiz olarak nitelendirmek olanaksızdır; zira Altın Çağ, dönemin en önemli ismi sayılan Puşkin ve Puşkin geleneğini şöyle ya da böyle devam ettiren isimlerle anılırken Gümüş Çağ, her biri çok farklı yönelimlerde olan yazar, şair ve toplulukları bünyesinde taşır ve tek bir isim, yönelim yahut grupla anılamayacak kadar zengin bir dönemi imler. Öte yandan Gümüş Çağ, sanata özerkliğini kazandırmak adına sanatın hemen her alanında geleneksel olanın sorgulandığı bir döneme işaret ederek Altın Çă̆'dan ayrılır.

4 Wolfgang Kasack, Leksikon Russkoy Literaturly XX. Veka (Moskva: RİK «Kultura», 1996), 289. 
topluluk Çinari’yle ${ }^{5}$ tanışmasına kadar uzanır. Yine aynı yıl, gelecekte Gerçek Sanat Birliği’ne katılacak olan Zabolotskiy ve Gerçek Sanat Birliği'ne yakınlığıyla bilinen Oleynikov da Çinari'ye katılırlar. Buna karşın, Özlem Parer'in de sözünü ettiği gibi Çinari'nin, OBERİU'nun özü olduğunu düşünmek yanlıştır; zira Çinari'nin daha kendine dönük, dostane bir ruhu olduğu ve iki grubun birbirinden ayrı olarak değerlendirilmesi gerektiği belirtilir. ${ }^{6}$

Gerçek Sanat Birliği'nin, ilk halka açık gösterimi “Üç Sol Saat” (Три левых часа/ Tri levıh çasa), 24 Ocak 1928 tarihinde, Leningrad'da, “Dom Peçati”de gerçekleşir. Adından da anlaşılacağı şekilde üç kısımdan oluşan gösterinin ilk kısmında koro taktim edilir, Gerçek Sanat Birliği Bildirisi'nin okunmasının ardından K. Vaginov, N. Zabolotskiy, D. Harms, N. Kropaçev, İ, Bahterev, A. Vvedenskiy şiir okurlar. Bu sırada gecenin sunucusu üç tekerlekli bir bisiklete binerek olağanüstü figürler yapar. ${ }^{7}$ İkinci kısımda Daniil Harms'ın bu gece için özel olarak yazdığı tiyatro oyunu Yelizaveta Bam gösterime sunulur. Oyun şu kadroyla oynanır: GrinYelizaveta Bam, Maneviç-İvan İvanoviç, Varşavskiy-Pyotr Nikolayeviç, Vigilyanskiy-Baba, Babayeva-Anne, Kropaçev-Dilenci. Gecenin üçüncü ve son saatinde Aleksandr Razumovskiy ve Klementin Mintsa'nın yönettikleri “Kıyma Makinesi” (Мясорубка/ Myasorubka) adlı film gösterime sunulur. ${ }^{8}$

Geceye, Yelizaveta Bam oyunu damga vurur. Alışılageldik mantıksal forma tezat oluşturacak şekilde kurgulanan oyun boyunca neden-sonuç ilişkisinden bağımsız diyaloglar göze çarpar. Oyun kişilerinin bir anda birbirleri yerine geçmeleri, birinin başladığı cümleyi bir diğer oyun kişisinin tamamlaması, isimlerin sık sık değişmesi, kaygan bir zeminde olunduğu hissini vererek gerçeklik algısını kırar ve seyirciye, beklediğinden uzak bir teatral form sunar. Oyun boyunca altı çizilen -kanun namına çalıştığını iddia eden kişilerce- yakalanma ve öldürülme korkusu, Stalin dönemi Sovyet insanının korkularını gözler önüne sererken günümüz aydınıyla oyunun yazıldığı dönem arasında ilişki kurulmasını sağlar. Nitekim 1927'de yazılan oyunun son yıllarda pek çok ülke ve tiyatro topluluğunca oynanması, kullanılan dilin sahneleme açısından geniş olanaklar sunması kadar, meselenin evrenselliğiyle de alakalıdır. ${ }^{9}$

5 “Çinari” (Чинари) ismi, "rütbe” anlamına gelen "çin" (чин) kelimesinden türetilmiştir.

6 Mürüvvet Özlem Parer, "Rus Modernleşmesinde Son Avangart Fenomen: OBERIU (Bir OBERIU Günlüğü)", Ankara Üniversitesi Dil ve Tarih-Coğrafya Fakültesi Dergisi 53/2 (2013), 535.

7 Daniil İvanoviç Harms, Konstantin Konstantinoviç Vaginov, Nikolay Alekseyeviç Zabolotskiy, Nikolay Makaroviç Oleynikov, Aleksandr İvanoviç Vvedenskiy, İgor Vladimiroviç Bahterev, "Programma Veçera «Tri levıyh çasa»", Vanna Arhimeda, Der. Anatoliy Anatolyeviç Aleksandrov (Leningrad: Hudojestvennaya Literatura, 1991) Erişim 5 Mart 2018, https://ruslit.traumlibrary.net/page/sbornik-vanna-arhimeda.html.

8 Harms, Vaginov, Zabolotskiy, Oleynikov, Vvedenskiy, Bahterev, "Programma Veçera «Tri levıyh çasa»", Vanna Arhimeda.

9 Yapılan araştırmalar, oyunun 2006 yılında Romanya'da tiyatro topluluğu Teatrul Bulandra tarafından sergilendiğini (bkz. Bulandra per musica Elizaveta Bam, Erişim 14 Nisan 2018, http://www.bulandra.ro/en/ discontinued/183-elizaveta-bam.html); yine aynı yıl Moskova'da Fyodor Andreyeviç Pavlov tarafından sahneye konularak 2008 yılında Londra'da gösterime sunulduğunu (bkz. Elizaveta Bam, Erişim 14 Nisan 2018, http:// fyodorpavlovandreevich.com/featr/\#/elizaveta-bam/); 2013 yllinda LTT-Schauspiel tarafindan (bkz. Elizaveta Bam, Erişim 14 Nisan 2018, http://alt2.landestheater-tuebingen.de/spielplan/elizaveta-bam-3731); 2017'de Compagnie 
Kendilerini "sanatlarının dürüst işçileri"”0 olarak niteleyen Gerçek Sanat Birliği üyeleri, 1928 yılında ${ }^{11}$ yayınlanan bildirilerinde arzularının, "sanatın bütün türlerini aşmak ve onu dört bir yandan kuşatarak hayata sokmak" 12 olduğunu belirtirler. Topluluğun kendini tanımlama biçimine de yansıyan sosyalist izlekte misyon edinilen bu ilke bizi, Büchner'in Avangard Kuram'ına götürür.

“Öncü birlik” anlamına gelen “avangard” terimi, ilk kez 1830’lu-40’l1 yılların ütopyalar döneminde siyaset diline girer ve köklü dönüşümlerin bayraktarları anlamında kullanılır. ${ }^{13}$ Rusya'da olduğu gibi Avrupa'da da siyasetle iç içe olan avangard terimi, nihayetinde insanlığın bir sanat alemine ulaşacağını vaat eden sosyalist ütopyaların bu tasarısının gerçekleşmesinde sanata verilen öncü rolü ifade etmek üzere, ilk kez ütopyacı sosyalist Saint-Simon'un cemaatinde dolaşıma girer. ${ }^{14}$ Avrupa' da sanata yüklenen bu toplumu dönüştürme misyonu, ilerleyen dönemlerde reddedilir ve avangard sanatçılar için mesele, sanatın kendisi haline gelir. Ne var ki Rus avangardı gerek OBERİU gerekse diğer avangard topluluklar göz önünde bulundurulduğunda sosyalizmden bağlarını tümüyle koparamaz ya da koparmaya çalıştığ 1 an yok olur. Ekim Devrimi öncesi ve sonrası iktidara hizmet ettiği düşünüldüğü ölçüde özgür bırakılan Rus avangardının, Devrim gerçekleştikten sonra kontrol altına alınmaya çalışılmasıyla da ilişkili olan bu durum, başka şartlarda belki de bambaşka bir gelişme gösterecek olan Rus avangardına “ütopik” bir hava verir. Bu bağlamda OBERIUU'nun "sanatı aşma" ya da "sanatı kuşatıp hayata sokma" iddiası, bir yandan beklentiyi çok da karşılamayan Devrim sonrasında toplumsal ve kültürel koşulları "sanat" vasıtasıyla dönüştürme umudunu imlerken diğer yandan, bu amaç için var olan sanat kurumlarından sanatı kurtarma misyonunu kendine görev edinmiş bir topluluğa işaret eder. Eski sanatın proletaryayı tatmin etmediğinin yeterince anlaşılmadığını düşünen OBERİUcular, SSCB tarafından talep edilen “devrimci sanatçı” anlayışını gülünç bulduklarını ifade ederek Rus

Buff Papier ve TOJO Theater Bern ortak yapımıyla sahneye konduğunu gösteriyor (bkz. Bam, Erişim 14 Nisan 2018, http://www.buffpapier.ch/bam.html). Günümüzde Yelizaveta Bam oyununu oynayan tiyatro topluluklarıysa şöyledir: Berlin Maksim Gorki Tiyatrosu, prömiyer tarihi: 14 Nisan 2018 (bkz. Premiere: Elizaveta Bam, Erişim 14 Nisan 2018, http:/gorki.de/en/elizaveta-bam/2018-04-14-1800); Rusya Devleti Sahne Sanatları Enstitüsü, XIV. Moskova Uluslararası Tiyatro Festivali “Tvoy Şans” (Your Chance) kapsamında gösterim tarihi: 21 Nisan 2018 (bkz. Yelizaveta Bam, Erişim 14 Nisan 2018, http://nastrastnom.ru/play/elizaveta-bam/); İrkutsk N. P. Ohlopkov Akademik Dram Tiyatrosu, en yakın gösterim tarihi: 13 Nisan 2018 (bkz. Elizaveta Bam, Erişim 14 Nisan 2018, http://www.dramteatr.ru/spectacle/elizaveta-bam); Litvanya Ulusal Dram Tiyatrosu ve Vilnius Şehir Tiyatrosu ortak yapımı, prömiyer tarihi: 2015, en yakın oyun tarihi: 19 Mayıs 2018 (bkz. Elizabeth Bam, Erişim 14 Nisan 2018, http://www.teatras.1t/en/productions/daniil_kharms_elizabeth_bam/).

10 Daniil İvanoviç Harms, Konstantin Konstantinoviç Vaginov, Nikolay Alekseyeviç Zabolotskiy, Nikolay Makaroviç Oleynikov, Aleksandr İvanoviç Vvedenskiy, İgor Vladimiroviç Bahterev, "Deklaratsiya OBERIUU", Vanna Arhimeda, Der. Anatoliy Anatolyeviç Aleksandrov (Leningrad: Hudojestvennaya Literatura, 1991) Erişim 5 Mart 2018, https://ruslit.traumlibrary.net/page/sbornik-vanna-arhimeda.html

11 OBERIU Deklarasyonu, 1928 yılında “Afişa Dom Реçati” (Афиша Дом Печати) adlı derginin 2. sayısında yayınlanmıştır.

12 Harms, Vaginov, Zabolotskiy, Oleynikov, Vvedenskiy, Bahterev, "Deklaratsiya OBERİ", Vanna Arhimeda.

13 Peter Bürger, Avangard Kuramı, çev. Erol Özbek, Şeyda Öztürk (İstanbul: İletişim Yayınları, 2017), 10.

14 Bürger, Avangard Kuramı, 10-11. 
edebi kültürünün üzerine oturduğu Batılı burjuva çeviri edebiyatını ve "kitap depolarını dolduran hurda kă̆ıtlarını" hatırlatırlar. ${ }^{15}$

1917 Devrimi’nden sonra Halk Eğitim Komiserliği’ne getirilen Lunaçarski'nin ${ }^{16}$ sorumluluğuna verilen kültür-sanat işleri, devrimin başlarında onu sahiplenen avangard sanatçılarla iş birliği içinde yürütülür. Bu durum, bir yandan devrim öncesinden beri tartışılagelen "devrimin dili" ile alakalıdır. Toplumsal yapıda yaşanması umut edilen büyük bir değişimi haber veren devrim sanatının, alışılagelmiş sanatsal formlardansa kökten yenici bir dile ihtiyacı olduğu avangard sanatçıların ortak fikridir. Diğer yandan Lunaçarski'nin ifade ettiğine göre "sanatçılar arasındaki gerçekçiler, devrimden hemen sonra devrimin kazanımlarına karşı kayıtsı, hatta düşmanca bir tavır al[ırlar]. (...) Buna karşılık "solcu” sanatçılar, sivri deneylerin, empresyonizm sonrası deneylerin temsilcisi sanatçllar, devrime hararetli bir tepki ver[irler]. " ${ }^{17} \mathrm{Bu}$ sebepledir ki 1920 yilında Tatlin ${ }^{18}$ tarafindan "sanatsal ve yararl formlar birleştir[il]erek, sanat ile hayat arasında bir çeşit sentez yaratıldı̆̆ "'19 fikrine dayanılarak yapılan ütopik-konstrüktivist yapı Tatlin Kulesi, Mayakovski’nin deyimiyle “Ekim'in ilk nesnesi” dir. ${ }^{20}$ Gelgelelim ilerleyen yıllarda avangard sanata bakış değişir. "1928'de ilan edilen Kültür Devrimi'yle birlikte, önce avangard karalanır; Devrim'le ve komünizmle olan ilişkisi ters yüz edilir. Íkinci etapta, 1932'de Parti'nin yayınladı̆̆ 'Edebi ve Sanatsal Örgütlerin Yeniden Düzenlenmesi' yolundaki kararnameyle, mevcut olan bütün cemiyetler, birlikler, gruplar dăgıtılır." ${ }^{21}$ Bunda etkili olan düşünce, özellikle 1920’lerden sonra etkinlik kazanan "Sovyet insanını" yaratma girişimidir. ${ }^{22}$ Özerk grupların dağıtılmasının ardından kurulan Sanatçılar Birliği ile sanat, denetlenmeye tabi tutularak merkezileştirilir. Ardından 1934 yılı ağustos ayında gerçekleşen Sovyet Yazarları I. Kongresi'nde Jdanov’un yaptığı konuşmayla

15 Harms, Vaginov, Zabolotskiy, Oleynikov, Vvedenskiy, Bahterev, "Deklaratsiya OBERİU", Vanna Arhimeda.

161875 yılında doğan A. V. Lunaçarski, siyasal etkinliğe 1892'de başlar. Yurt dışında eğitim alan Lunaçarski, sanatla devrim fikriyle iç içedir. 25 Ekim (1 Kasım) 1917'de Sovyetler Kurultayı'nın ikinci oturumunda Lenin'in imzaladığı “işçilere, askerlere, köylülere" seslenen ve iktidarın Sovyetlere geçtiğini açıklayan bildiriyi o okur. Aynı gece, Lenin'in önerisiyle Halk Eğitim Komiseri seçilerek Sovyet yönetiminin ilk bakanı olur. Bu komiserlikle, ülkenin bütün kültür-sanat işlerini üstlenir. 21 Aralık 1933’te vefat eden Lunaçarski, 1929 yılına kadar Halk Komiserliği görevini sürdürür. Detaylı bilgi için bkz. Anatoli Lunaçarski, Sosyalizm ve Edebiyat, çev. Asım Bezirci, (İstanbul: Evrensel Kültür Kitaplı̆̆ı, 1998), 9-32.

17 Anatoli Lunaçarski, Devrim ve Sanat, çev. Süheyla Kaya, Saliha Nazlı Kaya, (İstanbul: İnter Yayınları, 2000 ), 138.

18 Konstrüktivizmin kurucusu olan Tatlin, başta kübizmin kolaj mantığından etkilenir ve çeşitli malzemeler kullanarak deneysel çalışmalar yapar. Ne var ki başlangıçta herhangi bir yarar gözetmeyen bu çalışmalar, zamanla "hayata form verme" amacı taşır ve Artun'un da belirttiği gibi sanatın özerkliğini yıkarak konstrüktivistlerin sanatlarının "üretim" olarak değerlendirilmesine sebep olur. Detaylı bilgi için bkz. Ali Artun, Sanatın İktidarı 1917 Devrimi, Avangard Sanat ve Müzecilik, (İstanbul: İletişim Yayınları, 2016), 59-63.

19 Artun, Sanatın İktidart 1917 Devrimi, Avangard Sanat ve Müzecilik, 87.

20 Artun, Sanatın İktidart 1917 Devrimi, Avangard Sanat ve Müzecilik, 91.

21 Artun, Sanatın Iktidarı 1917 Devrimi, Avangard Sanat ve Müzecilik, 158.

22 Çarlık Rusya'sının Rus milliyetçiliğine karşın Bolşevik ihtilali din, dil, ırk ayrımı gözetmeyen bir Sovyetler Birliği iddiası taşır. Fakat bu iddianın, özellikle Stalin dönemi izlenen politikalara bakıldığında ütopik bir hedef olmaktan ileri gidemediği görülür. Bununla birlikte 1920'li y1llardan itibaren Sovyetlerde "homo-Sovyeticus" yani Sovyet İnsanı yaratma çabaları başlar. Detaylı bilgi için bkz. Merve Suna Özel, "Stalin Dönemi Rus Milliyetçiliği ve Politikaları”, Kırıkkale Üniversitesi Sosyal Bilimler Dergisi 4/2, (2014), 103. 
"sosyalist gerçekçilik" resmî ideoloji haline getirilir. ${ }^{23}$ Gerçek Sanat Birliği üyeleri, önce baş tacı edilen sanatçı ve edebiyatçıların, devrimi takip eden yıllarda karalanıp sanatlarını yapmalarına kısıtlama getirilmesine anlam veremediklerini şu sözlerle aktarırlar: "Filonov Okulu'nun neden Akademi'den çıkmaya zorlandı̆̆ına, Maleviç’in mimari çalışmalarını SSCB'de neden sergileyemediğine, Terentyev'in 'Müfettiş'inin neden böyle saçma bir şekilde ıslıklandı̆̆ına anlam veremiyoruz. Arkasında çok sayıda liyakat ve başarıya malik sözüm ona sol sanatın, neden umutsuz bir süprüntü ya da daha da kötüsü 'şarlatanlık' olarak değerlendirildiğini anlamıyoruz. Bu vahşi yaklaşımda nice içsel sahtekarlık, nice sanatsal çürümüşlük gizleniyor. "² Gelgelelim manifestolarında, sanatlarını icra etmekten alıkonulan, kendi deyimleriyle "gerçek devrimcileri” savundukları bu satırlardan kısa süre sonra, 1931 yılında, Gerçek Sanat Birliği’nin kurucu ismi Daniil Harms, topluluğun diğer üyeleri Vvedenskiy ve Bahterev ile birlikte, Sovyet karşıtı bir yazarlar grubuna üye olmaktan suçlu bulunarak tutuklanır. ${ }^{25}$

OBERIUUcular, gerçekten de sanatı dört bir yandan kuşatırlar; zira OBERİU Bildirisi’nde topluluğun dört kola ayrıldığı belirtilir. Bunlar: Edebiyat, görsel sanatlar, tiyatro ve sinemadır. Yine bildiride grubun, bir müzik branşını da kendine katmak için çalışmalar yaptığı ifade edilir. ${ }^{26}$ Görüldüğü üzere Gerçek Sanat Birliği, aynı dönem varlık gösteren diğer pek çok gruptan farklı olarak sistematik bir metodolojiye dayanan bir çalışma sistemine sahiptirler ve bu yönleriyle profesyonel bir topluluk imajı çizerler.

OBERIU ile ilgili bir başka yanılgı, onların Rus fütürizminin bir uzantısı ya da devamı oldukları yönündedir. Rus avangardının başını çeken fütürizm, 1912 yılında yayınlanan "Toplum Beğenisine Tokat" ${ }^{27}$ adlı manifestoyla gündeme gelir. Kendine daha çok şiir ve resim alanında takipçiler bulan fütürizmin, özellikle resim alanında araladığı kapı, ileriki safhalarda pek çok avangard akıma evrilir. Fütüristler, çağın hızına ayak uydurmayı ilke edinerek eski sanat anlayışını reddederler ve yeni sanatı yaratmaya girişirler. Onlara göre “Akademi ve Puşkin, anlaşılmaz hiyerogliflerdir. "28 Yine manifestolarında Puşkin’i, Dostoyevski’yi, Tolstoy’u

23 Yaptığı konuşmada Jdanov, yalnızca "sosyalist inşanın eti ve kanı olan Sovyet edebiyatının” gerçekten ileri, içerik bakımından zengin ve devrimci bir edebiyat olabileceğini söyler. Jdanov’a göre gizemciliğin ve softalığın alıp yürümesi, pornografi merakı burjuva kültürünün çöküşünün belirleyici özellikleridir. Sovyet edebiyatının gücü, yeni bir davaya, sosyalist inşa davasına hizmet etmesinden gelir. Detaylı bilgi için bkz. Andrey Aleksandroviç Jdanov, Edebiyat Müzik ve Felsefe Üzerine, çev. Fatmagül Berktay Baltalı, (İstanbul: Kaynak Yayınları, 1996), 13-20.

24 Harms, Vaginov, Zabolotskiy, Oleynikov, Vvedenskiy, Bahterev, "Deklaratsiya OBERIU", Vanna Arhimeda.

25 Grup aynı yıl dağıtılır; ancak grup üyelerinin dostluğu sürer. 1941 yılında Daniil Harms sosyalizm karşıtı propaganda yapmaktan tekrar tutuklanır ve topluluğun neredeyse hepsiyle aynı kaderi paylaşarak 1942 yılında, henüz 36 yaşındayken açlıktan ölür. Grubun bir diğer üyesi Aleksandr Vvedenskiy de 1941 yılında devrim karşıtı ajitasyon yapmaktan tutuklanır ve Kazan'a götürülmek üzere yola çıkarılır. Ancak daha Kazan'a varamadan yolda, akciğer iltihabından ölür. 37 yaşında ölen şairin mezarı bilinmemektedir. Grubun diğer üyelerinden Vaginov 1934 yılında henüz 35 yaşındayken tüberkülozdan ölür. Zabolotskiy, 1938 yılında gönderildiği Sibirya sürgününden 1946 yılında Moskova’ya döndüğ̈nde Sovyet Yazarlar Birliği’ne katılır, 1958 yılında Moskova’da ölür.

26 Harms, Vaginov, Zabolotskiy, Oleynikov, Vvedenskiy, Bahterev, “Deklaratsiya OBERİU”, Vanna Arhimeda.

27 David Burlyuk, Nikolay Burlyuk, Aleksey Kruçyonıh, Vasiliy Kandinskiy, Benedikt Livşits, Vladimir Mayakovskiy, Viktor Hlebnikov, Poşeçina Obşestvennomu Vkusu (Moskva: G. L. Kuzmina, 1912).

28 Burlyuk, Burlyuk, Kruçyonıh, Kandinskiy, Livşits, Mayakovskiy, Hlebnikov, Poşeçina Obşestvennomu Vkusu, 3. 
modernite vapurundan aşağ atmay1 $^{29}$ öneren fütüristler, sembolizme ${ }^{30}$ özgü belirsizlikten, mistisizmden, kapalılıktan uzaklaşarak merkeze insanı koyarlar ${ }^{31}$ ve yeni sözcükler üreterek yeni bir şiir dili yaratırlar. OBERIUUcuların itirazı da bu noktada başlar. Önde gelen iki fütürist gruptan biri olan kübofütürizmin ${ }^{32}$ takipçileri, kelimenin imkanlarını genişletmek için iki yönteme başvururlar. Bunlardan ilki, eski kelime köklerinden yeni kelimeler türetmektir (bu durumda kelimenin anlamı korunur); "akıl ötesi” (заумь/ zaum) diye adlandırılan ikinci yöntem ise anlamdan yoksun, yeni sessel kompleksler üretmektir. ${ }^{33} \mathrm{Bu}$ dili kullanan fütüristlere "akıl ötesi yazar” anlamına gelen “zaumnik” (заумник) adı verilir. Gerçek Sanat Birliği üyeleri, "akıl ötesi yazar" olarak adlandırılmaktan duydukları rahatsızlığı şu sözlerle dile getirirler: "Şimdiye kadar birileri bizi "akıl ötesi yazarlar" [заумник / zaumnik] diye değerlendirdi. (...) Bize, akl ötesinden daha hasmane bir okul yok. Insanlar, kemiklerinin iliklerine kadar gerçek ve somutturlar; biz, kelimeyi iğdiş eden ve onu etkisiz, anlamsı bir meleze dönüştürenlerin baş düşmanlarlyız. Kendi eserlerimizde biz, konunun ve kelimenin anlamını genişletip derinleştiriyoruz; ancak asla tahrip etmiyoruz." 34 Topluluğun ortak manifestosunda yer alan bu ifadelere karşın Daniil Harms tarafından yazımı 1927 yılının aralık ayında biten Yelizaveta Bam adlı oyun, tam da "akıl ötesi" denen bu dille bezelidir.

29 Burlyuk, Burlyuk, Kruçyonıh, Kandinskiy, Livşits, Mayakovskiy, Hlebnikov, Poşeçina Obşestvennomu Vkusu, 3.

30 Rus sembolizmi, 1892 yılında Merejkovskiy’nin yaptı̆̆ “ “Geri kalmışlı̆̆ın Sebepleri ve Yeni Çă̆daş Rus Edebiyatı Akımları ” başlıklı konuşmayla başlar (Detaylı bilgi için bkz. Dmitriy Sergeyeviç Merejkovskiy, O priçinah upadka i o novıh teçeniyah sovremennoy Russkoy literaturıy (S. Peterburg: B. M. Volfa, 1893). Merejkovskiy, yeni sanat akımının ilk manifestosu sayılan bu eserde Turgenyev, Gonçarov, Dostoyevski, Tolstoy, Nekrasov gibi yazarların eserlerini ele aldıktan sonra yeni sanat çağrısı yapar. Rus sembolizminde iki grup olduğu söylenebilir. Bunlar Birinci Kuşak (büyük, kıdemli/ старшие) sembolistler ve İkinci Kuşak (küçük, genç/ младшие) sembolistlerdir. Sembolistler, Avrupa'daki öncülleri gibi müzikaliteyi anlamın önüne koyarlar. Sözcüğü, alışılageldik anlamından kurtararak ona daha derin, simgesel bir anlam yükleyen sembolistler, böylece kelimenin özerkliğini kazandığını düşünürler ve mistik bir çerçeveden görünenin ardındaki görünmeyen gerçekliğe dikkat çekerler.

31 Fütüristlerle hemen hemen aynı dönem, sembolistlerin kelimenin anlamını muğlaklaştırmasına karşı sözcüğe asıl anlamını geri vererek onu belirsizlikten kurtaran bir başka akım akmeizm ortaya çıkar. Yunanca "doruk", "en üst seviye" anlamlarına gelen "akme" kelimesinden türetilen akmeizm, sembolist mistisizmi terk ederek gözle görülen somutluğa odaklanır ve sembolistlerin peşinden gittiği "görünenin ardındaki görünmeyeni” bir kenara bırakarak evrensel kültüre, insana, insanın ilksel duygularına odaklanır. "Şairler Atölyesi” altında toplanan akmeistlerin başlıca düşünceleri, Gumilyov’un “Sembolizmin Mirası ve Akmeizm” ve S. Gorodetskiy'nin “Çă̆daş Rus Şiirinde Bazı Akımlar” adlı yazılarının yayınlandığı Apollon adlı dergide dile getirilir. Bununla birlikte akmeizm fütürizmden, hem düşünsel-felsefi açıdan hem de biçimsel açıdan ayrılır. Detaylı bilgi için bkz. Nikolay Gumilyov, "Nasledie simvolizma i akmeizm”, Apollon 1 (1913), $42-45$ ve Sergey Gorodetskiy, "Nekotorıe teçeniya v sovremennoy russkoy poezii", Apollon 1 (1913), 46-50.

32 Önde gelen iki gruptan diğeri, Peterburg merkezli Egofütüristlerdir; ancak bunlar dışında, içine Boris Pasternak, Sergey Borbov gibi isimlerin dahil olduğu "Tsentrefüj” ve "Mezonin Poezii" gibi başka fütürist topluluklar olduğu da bilinmektedir. Bunlar arasından özellikle resim alanında etki gösteren kübofütürizm, bünyesinde Gonçarova, Rozanova ve Gerçek Sanat Birliği’ne yakınlığıyla bilinen Maleviç gibi ressamlar bulundurur. Yine kübofütürist ressamların Hlebnikov, Kluçenıh gibi fütürist şairlerle ortak çalışmalar yaptığı bilinir. Bir dönem "kübofütürizmin yeni sanata giden tek yol" olduğunu savunan Maleviç (Aktaran Ali Artun, Sanatın İktidarı 1917 Devrimi, Avangard Sanat ve Müzecilik (İstanbul: İletişim Yayınları, 2016), 44.), ileriki dönemlerde aradığını bir başka avangard akım olan süprematizmde bulacaktır.

33 Vladimir Solovyov, Nikolay Minskiy, İnnokentiy Annenskiy, Fyodor Sologub vd., "Kubofuturizm ("Gileya”)", Poeziya Serebryanogo Veka, Der. Boris Akimov (Moskva: Eskmo, 2007) Erişim 10 Mart 2018. https://iknigi. net/avtor-sbornik/59297-poeziya-serebryanogo-veka-sbornik-sbornik.html.

34 Harms, Vaginov, Zabolotskiy, Oleynikov, Vvedenskiy, Bahterev, "Deklaratsiya OBERIU', Vanna Arhimeda. 
Özlem Parer'in Rus fütürizmi üzerine yazdığı makalesinde belirttiği gibi 1913 yılında Kruçyonıh ve Hlebnikov tarafından geleneksel şiire bir karşı çıkış olarak "Salt Sözcük. Edebi Yapıtlar Hakkında" (Slovo kak takovoye. O hudojestvennıh proizvedeniyah) adlı fütürist bildiri kaleme alınır ve "Kruçyonıh ve Hlebnikov bu bildiride yer verdikleri

$$
\begin{aligned}
& \text { dir, bul, şçıl } \\
& \text { ybeşur } \\
& \text { skum } \\
& \text { vı so bu } \\
& \text { rlez } \\
& \text { ve } \\
& \text { pa-pa-pa } \\
& \text { pi-pi-pi } \\
& \text { ti-ti-ti } \\
& \text { v.b. }
\end{aligned}
$$

şeklinde yalnızca anlaşılmaz seslerle dolu şiirin, 'Puşkin'in tüm şiirlerinden çok daha ulusal' olduğunu savunurlar." 35 Fütüristlerce kaleme alınan bu anlamsız şiirlerle, eskiden fütürizme ilgi duyan fakat daha sonra "akıl ötesi” dili reddettiğini söyleyen şair ve yazar Daniil Harms'ın Yelizaveta Bam adlı oyununda, Pyotr Nikolayeviç adlı oyun kişisinin büyü yaparken kullandığı şu ifadelerin benzerliği dikkat çekicidir:

“Pyotr Nikolayeviç. Kurlybıyr daramur

\section{Diyndiri}

Slakattyr pakaradagu

Dıy kıy çiri kiri kiri

Zanudila habakula

He-e-el

$$
\text { (...) })^{36}
$$

35 Mürüvvet Özlem Parer, "Rus Edebiyatında Fütürizm”, Ankara Üniversitesi Dil ve Tarih-Coğrafya Fakültesi Dergisi 42/1-2 (2002), 51.

36 Çalışma boyunca Yelizaveta Bam oyununa referans veren oyuna ait parçaların hepsi için şu kaynaktan yararlanılmıştır: Daniil Harms. Rasskazıy i povesti. Yelizaveta Bam, erişim: 14 Nisan 2018, http://lib.ru/ HARMS/harms.txt. 
Yine oyunda kemanın çıkardığı sesse şöyledir:

“Keman. $\quad$ Papapipa

\section{Pa pa pi pa."}

Gerçek Sanat Birliği üyelerinin, manifestolarında fütüristlere özgü “akıl ötesi yazar” olarak anılmaktan rahatsızlıklarını dile getirmelerine karşın oyun boyunca buna benzer seslerle bir ritim tutturmaları ve yer yer anlamı olmayan ya da farklı kelimelerin bir araya gelmesiyle oluşan yeni sözcüklere yer vermeleri, fütüristlere açık bir gönderme olduğunu gösterirken tek başına anlamsız olan "akıl ötesi” dilin, teatral forma hizmet edecek şekilde kullanılmasında bir mani görmediklerini ortaya koyar. Yine oyunda geçen "Demire övgü, karborunduma! $!^{37} / O$ tutturur kaldırımları birbirine/ Ve ışıldayarak elektrikle /Hırpalar düşmanı ölünceye kadar!” gibi ifadeler, çağın devinimini “vida"nın kıvrımlarında bulan, elektrikli feneri ay ışığına tercih eden fütüristlerin şiirlerini akla getirir. Bununla birlikte devlet güçlerini temsil eden Pyotr Nikolayeviç'le bahsi geçen cümleleri dile getiren Baba'nın dövüşü, fütüristlerle Sovyetlerin çatışmasını hatırlatır. İkilinin dövüşü sonunda Pyotr Nikolayeviç’in yara almasına rağmen oyunun sonunda Yelizaveta Bam'ın tutuklanması, tek bir kazanan olduğuna işaret eder. Oyun boyunca devam eden "sol yandan gelen hamleleri saymak", "kızıl kırbaçla kendine mâni olmaya yeltenenin kemiklerini kırmak", "kızıl yakalı gömlek ve elindeki balta ile hamamböceğinin oturması" gibi ifadeler bu düşünceyi güçlendiren diğer göndermelerdir. Yine "kendi kendine yanan ve hiç sönmeyen ateş", devrim ateşini akla getirir. Gelgelelim Yelizaveta Bam oyunundaki mantık dışı öğelerin fazlalığ 1 ve Gerçek Sanat Birliği’nin saçmayla, anlamsızla aralarında kurdukları bağ düşünülünce kesin bir sonuca ulaşmak güçtür.

Son kertede Gerçek Sanat Birliği ya da OBERİU, A. Vvedenskiy, K. Vaginov, İ. Bahterev, N. Zabolotskiy, B. Levin, D. Harms gibi asal üyelerle K. Maleviç, N. Oleynikov, Y. Şvarts, P. Filonov gibi gruba yakınlığıyla bilinen isimleri bir araya getiren kolektif bir oluşumdur. Topluluğa dahil olan ve yakınlığıyla bilinen isimler arasında yazarlar, şairler, dramaturglar, ressamlar vardır. Her anlamda çok yönlü bir oluşum olan topluluğun üyeleri, yayınladıkları manifestoda Gerçek Sanat Birliği’nin alelade şekilde bir araya gelen kişilerden oluşmadığını vurgulayarak "bir edebiyat okulunun, tek tip rahiplerin bulunduğu bir manastırdan farksız olduğunun zannedilmesiyle”38 alay eder ve kendileri için özgürlüğün, gönüllülüğün esas olduğunu ifade ederler. Bu söylem, Sovyetler Birliği’nin sanat ve edebiyat, proletaryayı eğitmek adına tekeline almaya çalışarak baskılarını iyiden iyiye arttırdığı bir dönemde önemli bir siteme dönüşür. Hayatın mantığıyla sanatınkinin bütünüyle farklı olduğunu, sanatın kendi mantığı olduğunu düşünen Gerçek Sanat Birliği, alış1lageldik tüm sanat formlarına kafa tutar ve beklenmedik, saçma, absürt olanın peşinden gider. Onlara göre çağın gerçek gereksinimi,

37 Karborundum: Aşındırıcı madde olarak kullanılan silisyum karbürün ticaretteki adı.

38 Harms, Vaginov, Zabolotskiy, Oleynikov, Vvedenskiy, Bahterev, "Deklaratsiya OBERIU", Vanna Arhimeda. 
"dünyayl, bir işçinin devinim halindeki elleriyle sezmek; nesneyi, kültürün geçmişten süregelen bozulmuş çöpünden arındırmak[tır]"39 Bunun için çekinmeden haykırırlar: "Işste bu yüzden topluluğumuz OBERIU adını taşıyor: Gerçek Sanat Birliği. "40

\section{KAYNAKÇA / BIBLIOGRAPHY}

Solovyov, Vladimir; Minskiy, Nikolay; Annenskiy, İnnokentiy; Sologub, Fyodor vd. "Kubofuturizm

(“Gileya”)", Poeziya Serebryanogo Veka. Derleyen Boris Akimov. Moskva: Eskmo, 2007. Erişim 10 Mart

2018, https://iknigi.net/avtor-sbornik/59297-poeziya-serebryanogo-veka-sbornik-sbornik.html.

Artun, Ali. Sanat Manifestoları Avangard Sanat ve Direniş. İstanbul: İletişim Yayınları, İstanbul, 2015.

Artun, Ali. Sanatın İktidarı 1917 Devrimi, Avangard Sanat ve Müzecilik. İstanbul: İletişim Yayınları, 2016.

Burlyuk, David; Burlyuk, Nikolay; Kruçyonıh, Aleksey; Kandinskiy, Vasiliy; Livşits, Benedikt; Mayakovskiy,

Vladimir; Hlebnikov, Viktor. Poşeçina Obşestvennomu Vkusu. Moskva: G. L. Kuzmina, 1912.

Bürger, Peter. Avangard Kuramı, çev. Erol Özbek; Şeyda Öztürk. İstanbul: İletişim Yayınları, 2017.

Daniil Harms. Rasskazıy i povesti. Yelizaveta Bam. Erişim: 14 Nisan 2018, http://lib.ru/HARMS/harms.txt.

Gorodetskiy, Sergey. "Nekotorıe Teçeniya V Sovremennoy Russkoy Poezii", Apollon 1, (1913), 46-50.

Gumilyov, Nikolay. "Nasledie Simvolizma İ Akmeizm”, Apollon 1 (1913), 42-45.

Harms, Daniil. “Boje, kakaya ujasnaya jizn i kakoye ujasnoye u menya sostoyaniye”, Noviy Mir 2 (1992), 218.

Harms, Daniil İvanoviç; Vaginov, Konstantin Konstatinoviç; Zabolotskiy, Nikolay Alekseyeviç; Oleynikov,

Nikolay Makaroviç; Vvedenskiy, Aleksandr İvanoviç; Bahterev, İgor Vladimiroviç. Vanna Arhimeda. Der.

Anatoliy Anatolyeviç Aleksandrov. Leningrad: Hudojestvennaya Literatura, 1991. Erişim: 5 Mart 2018, https://ruslit.traumlibrary.net/page/sbornik-vanna-arhimeda.html.

Jdanov, Andrey Aleksandroviç. Edebiyat Müzik ve Felsefe Üzerine, çev. Fatmagül Berktay Baltalı. İstanbul: Kaynak Yayınları, 1996.

Kasack, Wolfgang; Leksikon Russkoy Literaturı XX. Veka. Moskva: Rik «Kultura», 1996.

Lunaçarski, Anatoli. Devrim ve Sanat, çev. Süheyla Kaya, Saliha Nazlı Kaya. İstanbul: İnter Yayınları, 2000.

Lunaçarski, Anatoli. Sosyalizm ve Edebiyat, çev. Asım Bezirci. İstanbul: Evrensel Kültür Kitaplığı, 1998.

Merejkovskiy, Dmitriy Sergeyeviç. O priçinah upadka i o novih teçeniyah sovremennoy Russkoy literaturly. S.

Peterburg: B. M. Volfa, 1893.

Özel, Merve Suna; "Stalin Dönemi Rus Milliyetçiliği ve Politikaları", Kırıkkale Üniversitesi Sosyal Bilimler Dergisi 4/2, (2014), 103.

Parer, Mürüvvet Özlem. "Rus Edebiyatında Fütürizm”, Ankara Üniversitesi Dil ve Tarih-Coğrafya Fakültesi Dergisi 42/1-2, (2002).

Parer, Mürüvvet Özlem. "Rus Modernleşmesinde Son Avangart Fenomen: Oberiu (Bir Oberiu Günlüğü)", Ankara Üniversitesi Dil ve Tarih-Coğrafya Fakültesi Dergisi 53/2 (2013).

Rozanov, Vasiliy Vasilyeviç. O Pisatelstve İ Pisatelyax. Moskva: İzdatelstvo «Respublika»,1995.

39 Harms, Vaginov, Zabolotskiy, Oleynikov, Vvedenskiy, Bahterev, "Deklaratsiya OBERIU", Vanna Arhimeda.

40 Harms, Vaginov, Zabolotskiy, Oleynikov, Vvedenskiy, Bahterev, "Deklaratsiya OBERIU", Vanna Arhimeda. 


\section{Bulandra Theatre}

Elizaveta Bam by Daniil Harms

Directed by Alexandru Tocilescu in 2006

Photos from Bulandra's Theatre Archieve

Photographer: Cosmin Ardeleanu





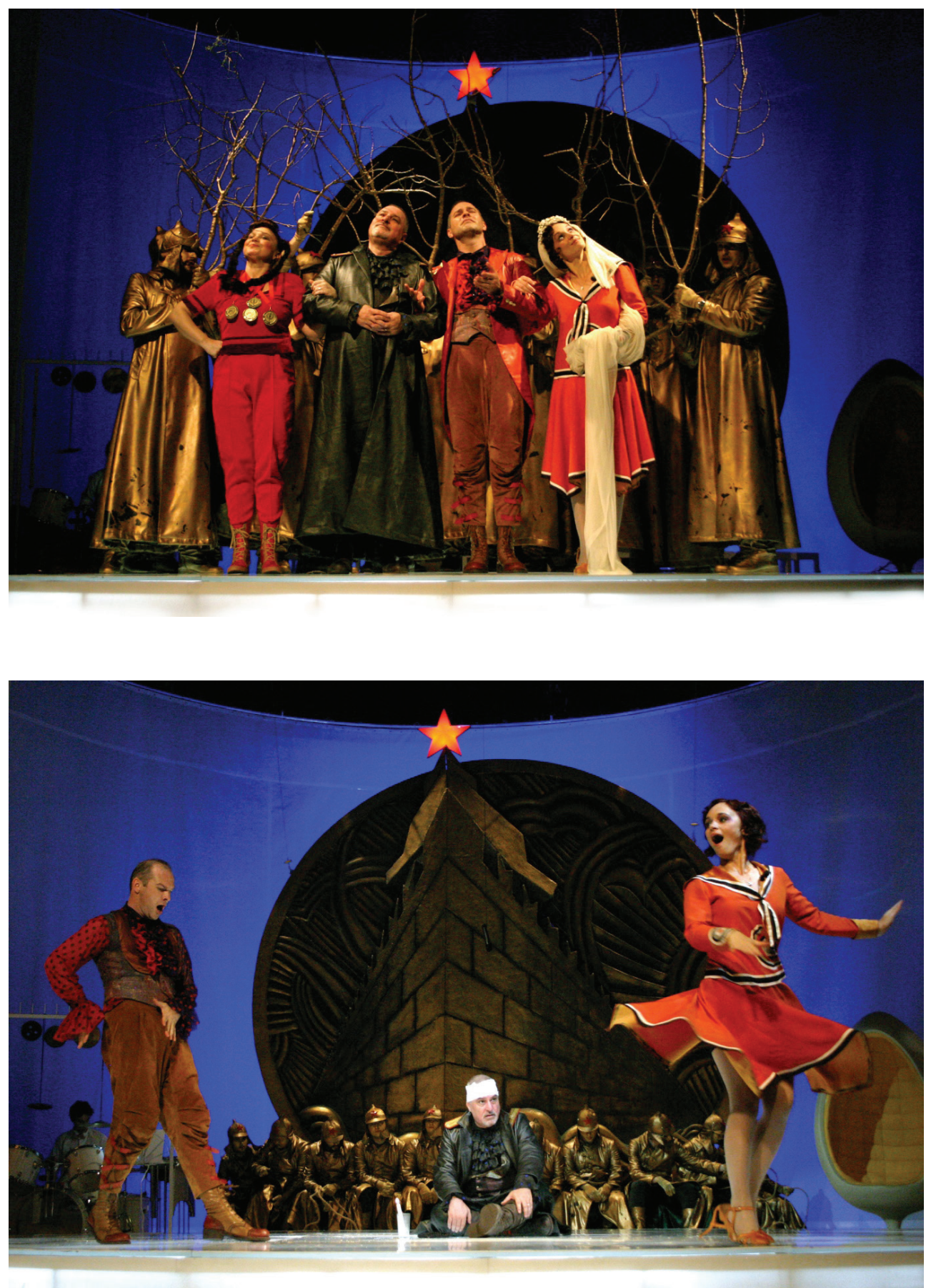

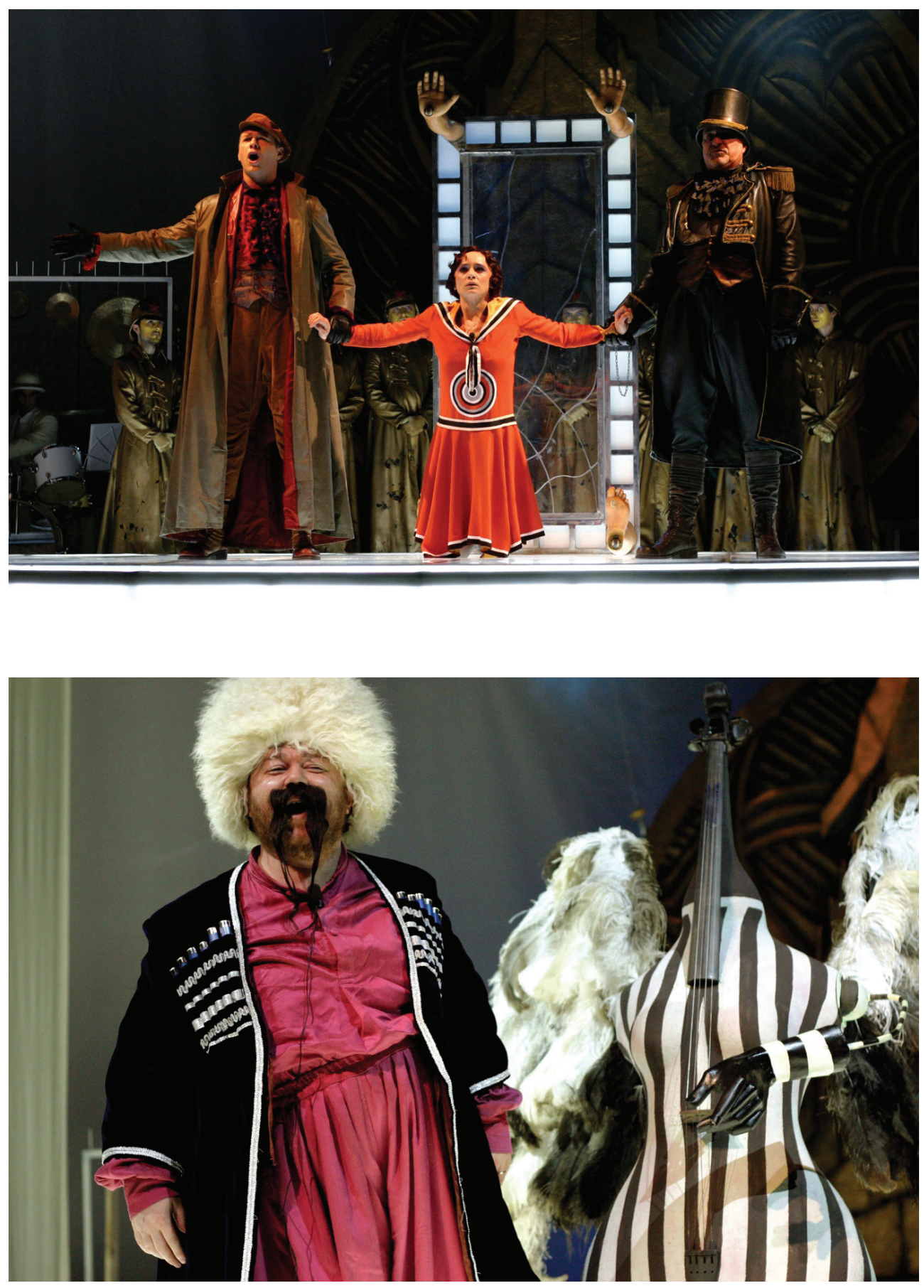

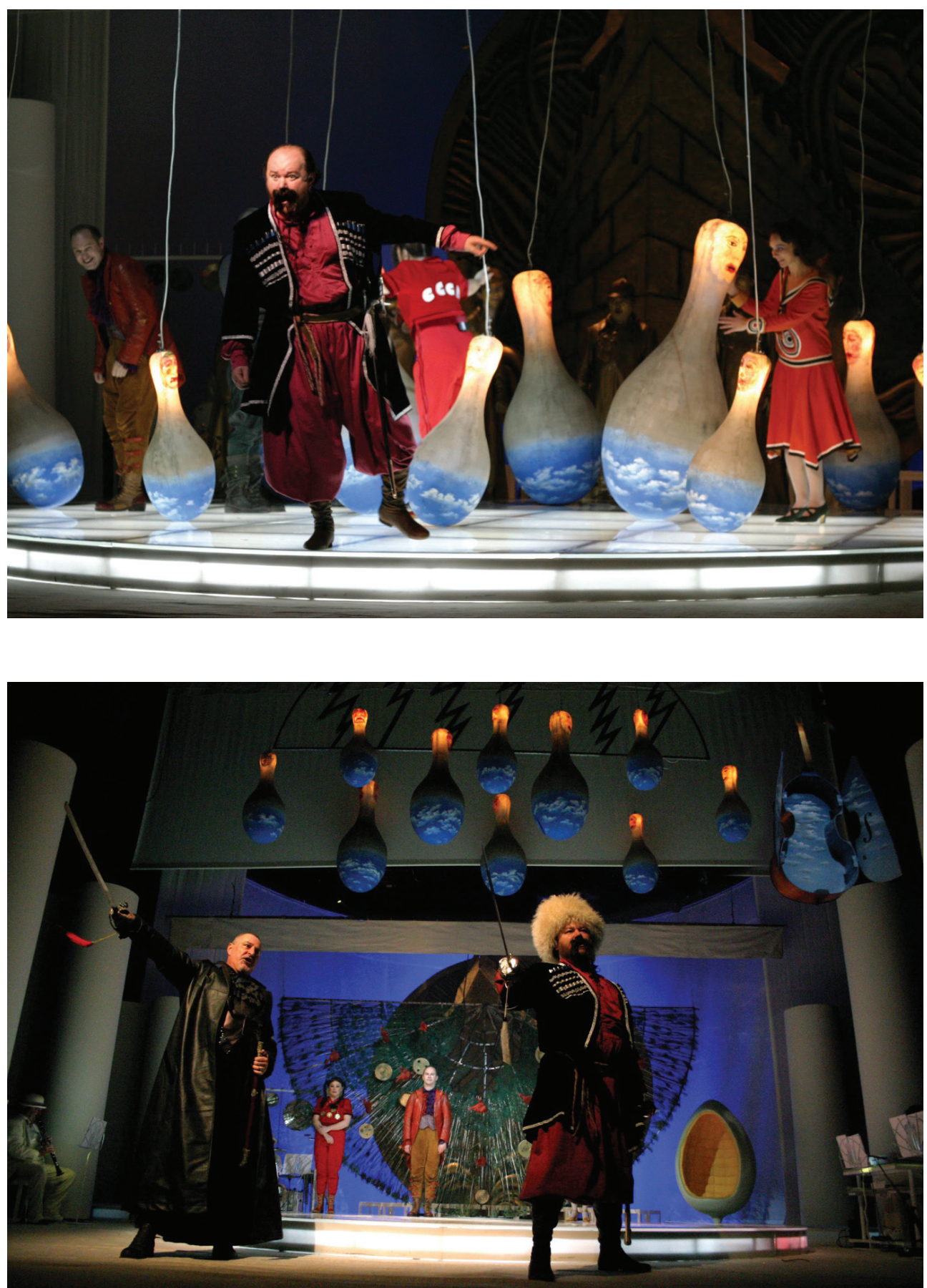


\section{Fyodor Andreyeviç Pavlov}

Yelizaveta Bam by Daniil Harms

Directed and written by Fyodor Andreevich Pavlov, in 2006, Moscow.

Associate director: Polina Kasyanova

Set design: Katya Bochavar

Costumes: Andrey Bartenev

Choreography: Dina Hussein

Music: Anton Sevidov

Lighting: Ivan Vinogradov

Photos from Fyodor Andreevich Pavlov's Website.








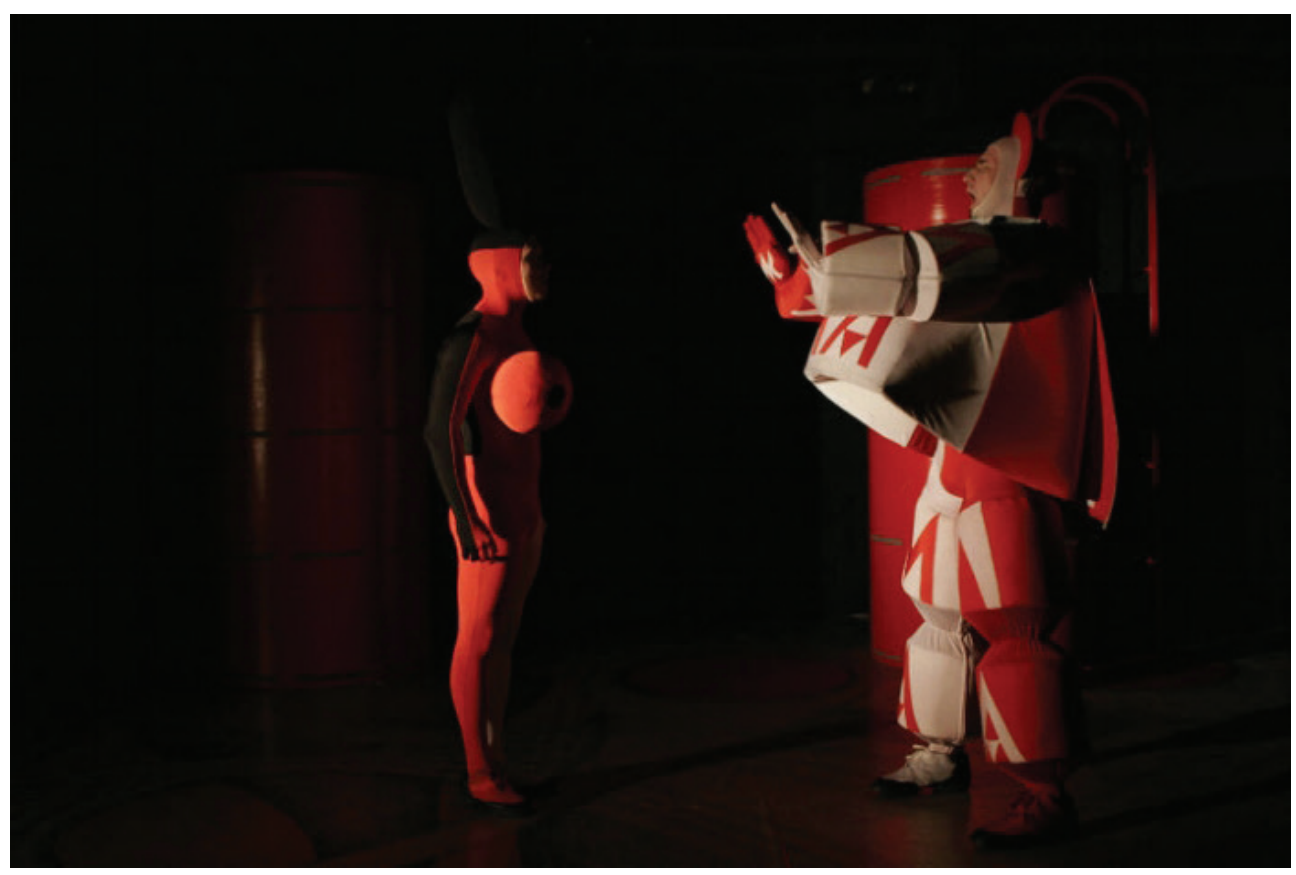

\section{Irkutsk Academic Drama Theater. N.P. Okhlopkova}

Streltsov Anatoly Andreevich - Director of the Irkutsk Academic Drama Theater. N.P.

Okhlopkova

Genre - Sentimental parody of the course of life

Staging and musical arrangement of Honored Art Worker of Russia Oleg Permyakov

Scenography of Alexander Plint, Honored Artist of Russia

Costume Designer - Oksana Gotovskaya

Assistant Director - Daria Rayanova

Photos: Anatoly Byzov and Roman Kirichenko.

The premiere took place on October 30, 2012.

Characters and performers:

Elizaveta Bam - art. Anastasia Pushilina

Peter Nikolaevich - art. Valery Zhukov

Ivan Ivanovich - art. Gleb Voroshilov, art. Yury Desnitsky

Daddy - hon. art. Of Russia Alexander Buldakov

Mommy - hon. art. Russian Tatiana Dvinskaya

Beggar - art. Anatoly Latsviev

Violin, Drum, Siren, 1st head, 2nd head, Guitar - artists Ivan Alekseev, Sergey Dubyansky, 
Ekaterina Konstantinova, Christina Razumova, Nikolai Strelchenko, Zoya Solovyova, Oleg Zaporozhets, Konstantin Ageev, Alyona Bochkareva, Anna Berlova, Yury Shelkovnikov
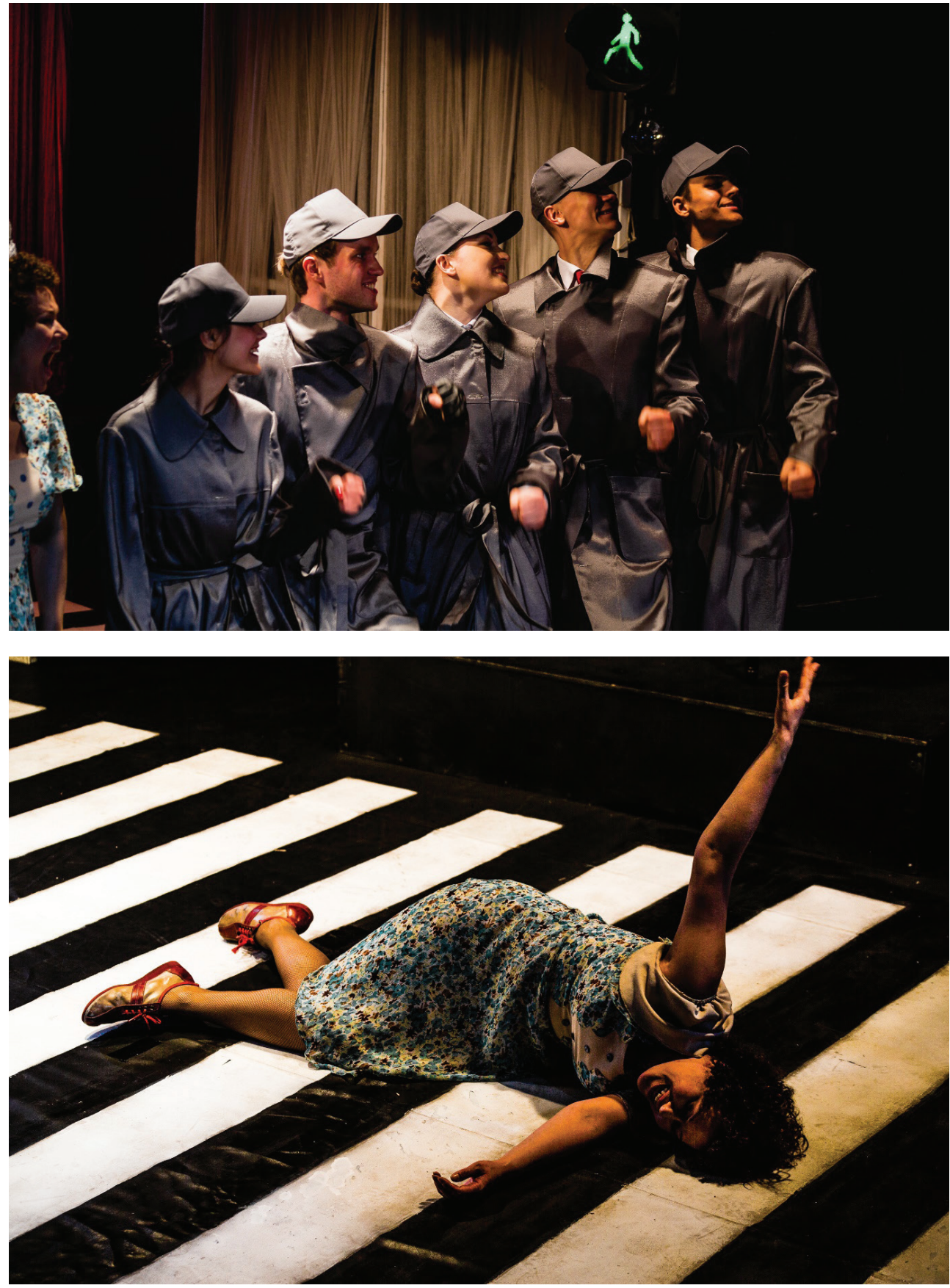






\section{Lithuanian National Drama Theare and OKT / Vilnius City Theatre}

Daniil Kharms. ELIZABETH BAM. Director Oskaras Koršunovas.

Lithuanian National Drama Theare and OKT / Vilnius City Theatre production Photo by Dmitrij Matvejev





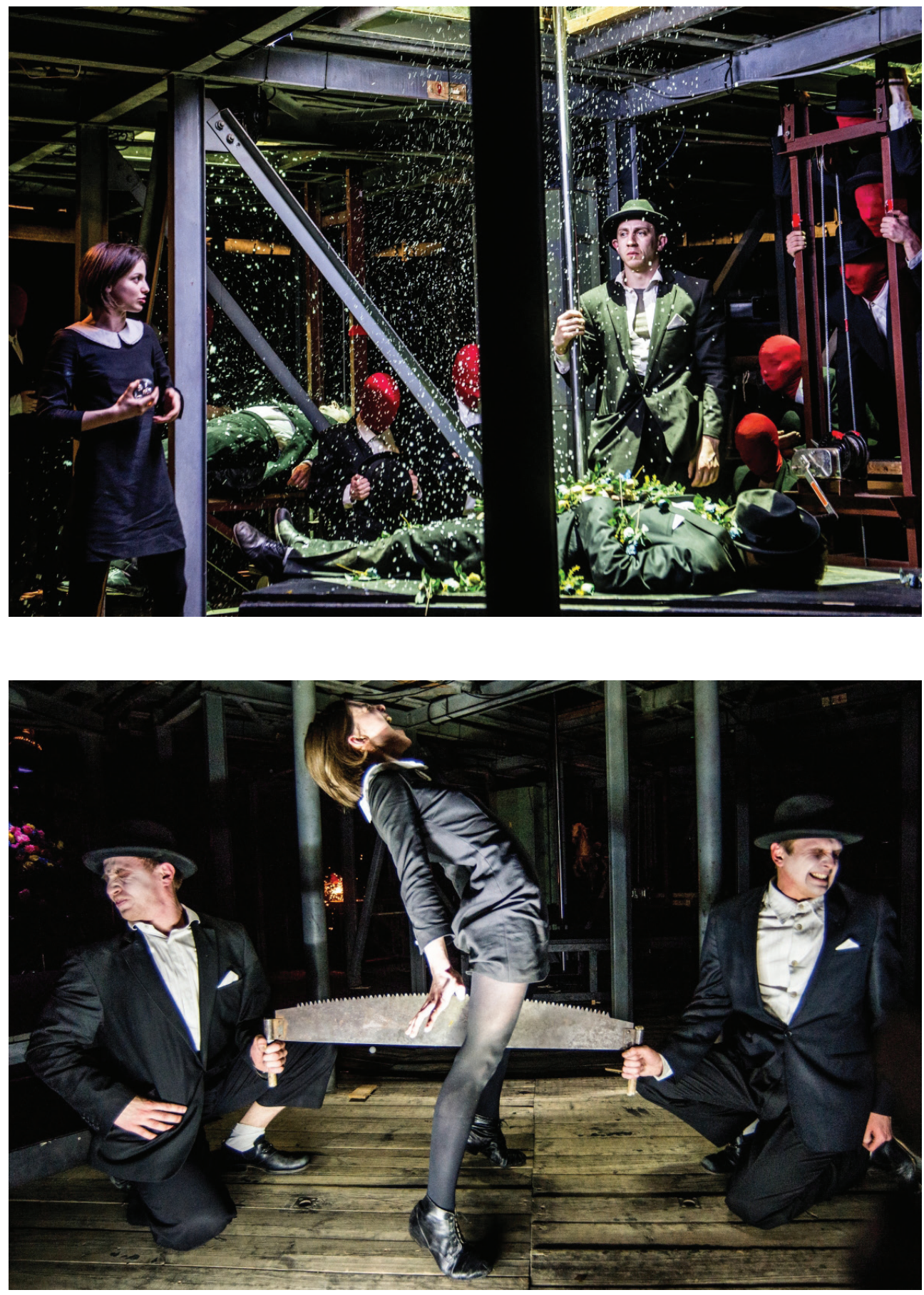


\section{Maxim Gorki Theater}

Elizaveta Bam by Daniil Charms

A Production of the Exil Ensemble

Directed by Christian Weise

Photo: Esra Rotthoff

Stage Design: Julia Oschatz

Live Music: Jens Dohle

Dramaturgy: Mazlum Nergiz

Fencing Choreography: Klaus Figge

Fechttraining: Jan Krauter

Cast: Maryam Abukhaled, Mazen Aljubbeh, Aram Tafreshian, Karim Daoud, Tahera Hashemi, Kenda Hmeidan

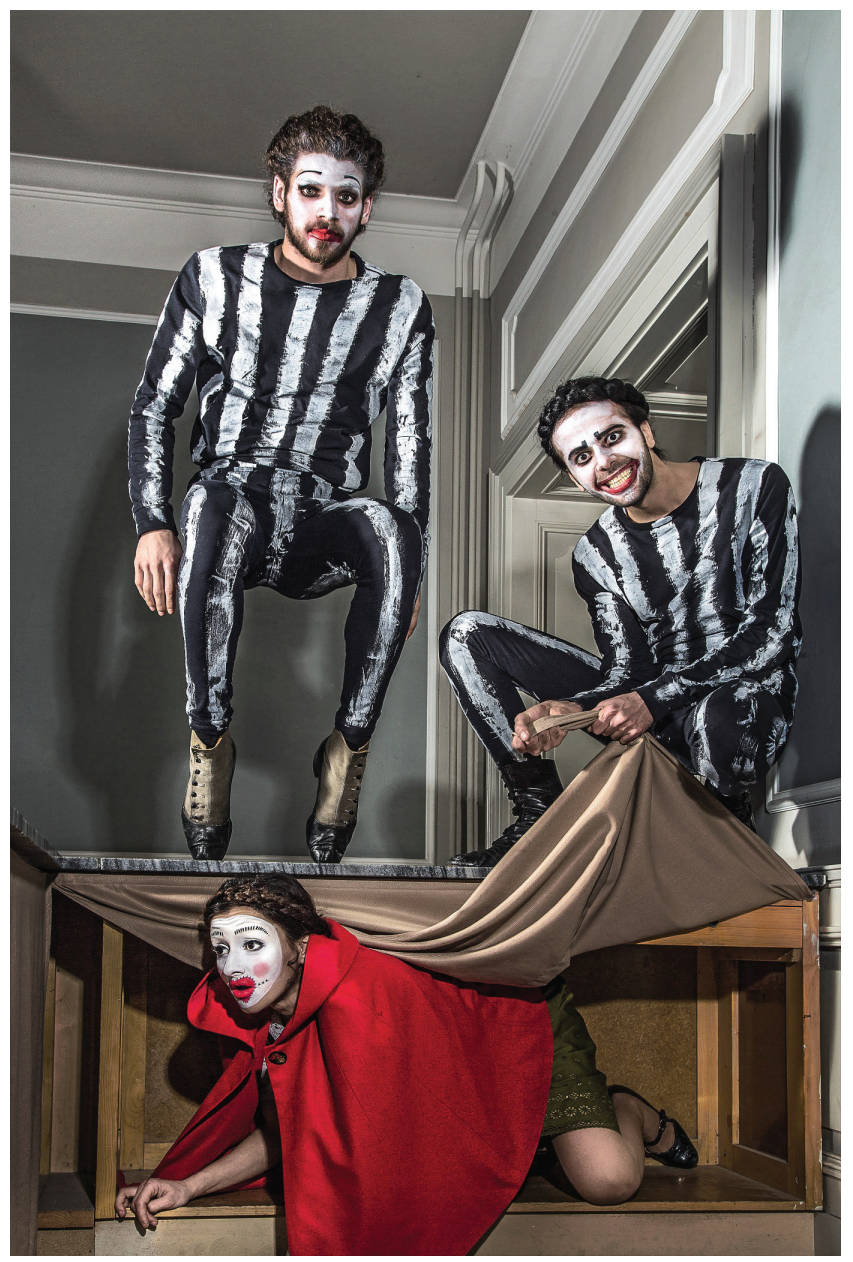




\section{Theater Compagnie Buffpapier}

Theater Compagnie Buffpapier / «BAM», 2017. Fotos: Jorma Müller
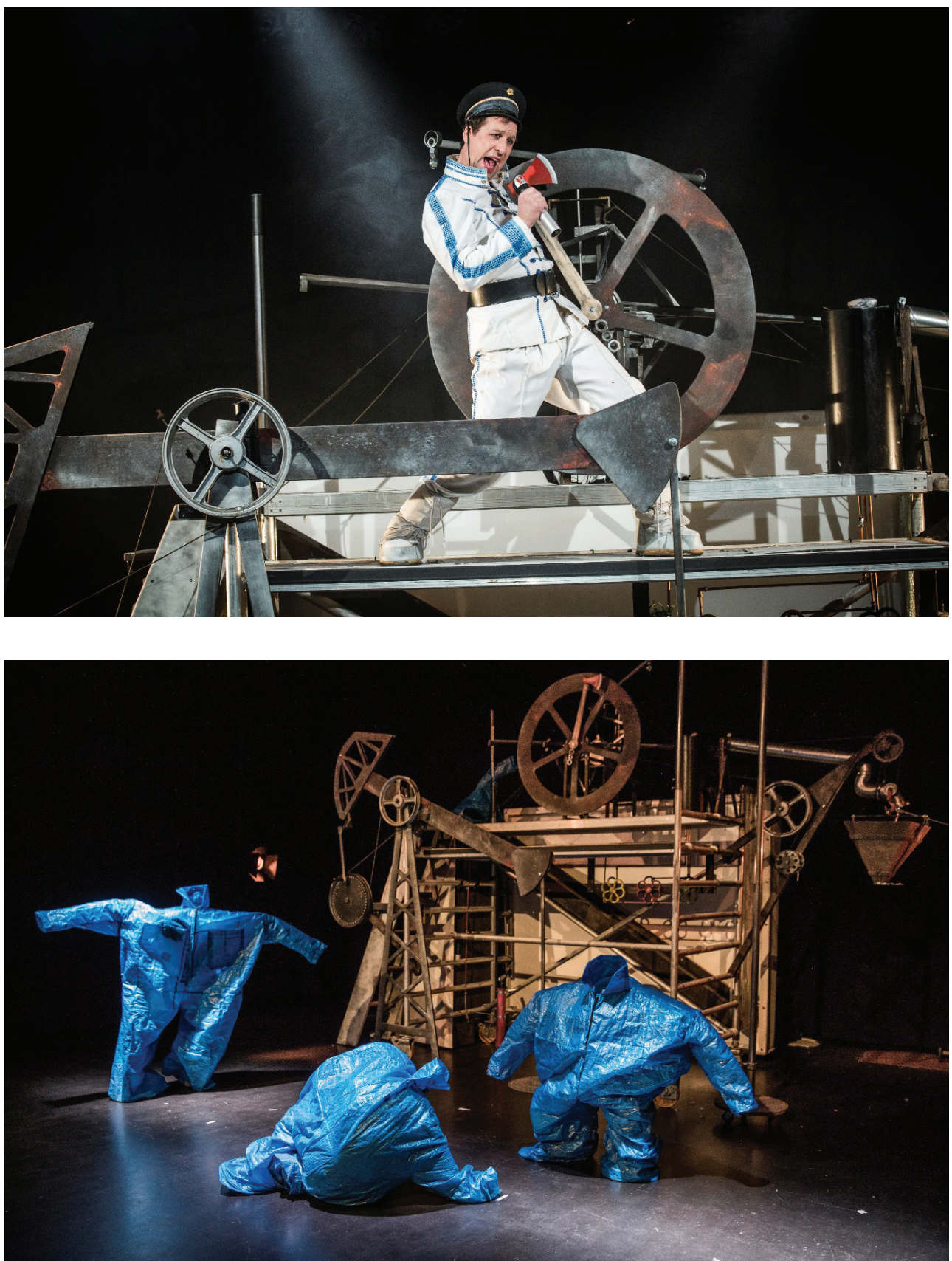


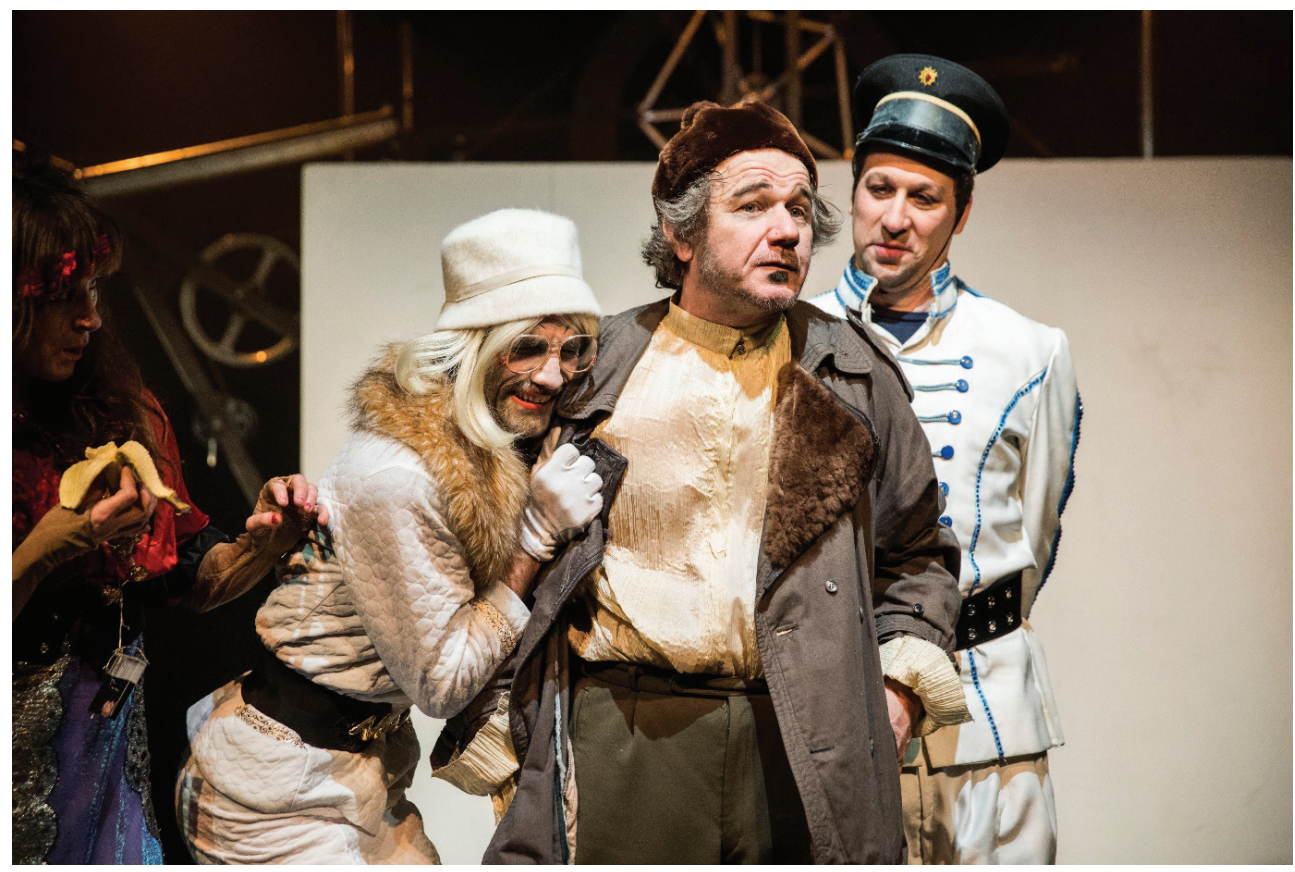


